\title{
Minnet ditt
}

Og nå er det stille

for alle de andre lydene enn dine

er de eneste som er igien her

og hendene vi holder hverandre med

de holder egentlig deg

og det tror jeg du vet

hva har vi nå da

jo

vi har minnet ditt og vi pakker det inn i silkepapir

putter det i lomma

og har det med på fest på eksamen

på tur hjem med trikken på butikken

til tannlegen og til tante og onkel

det er et bra minne å ha med

hvor enn det skulle være

for hvor skulle du ellers være enn her sammen med oss

for det er du uansett om du er her eller der

så god tur hils de andre så sees vi

også finner du ikke på noe tull der oppe ikke sant for da klemmer jeg litt ekstra hardt på minnet ditt jeg bare sier det

for da klemmer jeg litt ekstra hardt på minnet ditt

Trygve Skaug

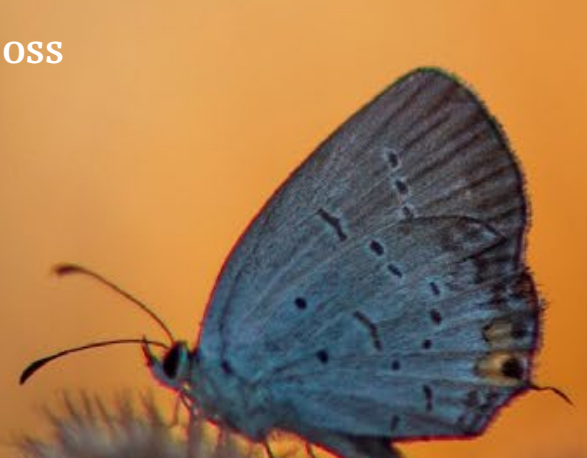

